ZESZYTY NAUKOWE UNIWERSYTETU SZCZECIŃSKIEGO

NR 884

EKONOMICZNE PROBLEMY USŁUG NR 119

2015

DOI: 10.18276/epu.2015.119-08

\author{
Anatoliy M. Kholodenko* \\ Mykola A. Vereschaka**
}

\title{
THE OPTIMIZATION OF PORT CHARGE RATES ON INLAND WATERWAYS
}

\begin{abstract}
Inland waterways play an important role in the transport system of the country because of their ability to provide large volumes of traffic at low cost. The port charges are an important source of financial resources for the infrastructure development of inland waterways and river ports. The most optimal port charge rate can be determined only by appropriate economic and mathematical models. Such models are built and investigated first in general form, then the necessary condition of port charge rate optimality is found. This optimal rate is a fixed point of continuous mapping, which translates non-empty compact convex set in itself.

The optimization of port charge rates by the criterion of maximum profit at different costs and competitors rates is shown on corresponding visual charts of dependencies. The models of port charge rates optimization on internal waterways under three various possible principal kinds of dependence of ship calls from these rates (linear, convex up, convex down) are also built. The relevant optimal values of port charge rates and the related amounts of ship calls and financial results are analytically determined. It makes possible to choose the adequate for real data type of dependence and determine its para-

* Anatoliy M. Kholodenko, PhD, Odessa National Maritime University, Faculty of Economy and Management, Department of Economic Theory and Cybernetics, e-mail address: anathol@ te.net.ua.

** Mykola A. Vereschaka, Ms, Odessa National Maritime University, Faculty of Port Engineering, Department of Hoisting Machinery Engineering and Port Technology Equipment, e-mail address: main@ukrvodshliah.org.ua.
\end{abstract}


meters by methods of mathematical statistics, then substitute these values into the appropriate formulas to obtain optimal values of port charges. This approach can be used to facilitate the development of inland waterways.

Keywords: rates of port charges, internal waterways, inland ports, optimization

\section{Introduction}

Inland waterways play an important role in the transport system of the country because of their ability to provide large volumes of traffic at low cost. For the maintenance of inland waterways and river ports in good condition appropriate financial resources are required, an important source of which are port charges. It is clear that between the magnitude of the rates of port charges and the number of ship calls an inverse relationship exists, i.e. while increasing these rates, the corresponding number of ship calls is reduced. The financial income will be missing for either a zero rate of port charges or too high, because of the absence of ship calls. So the best port charge rate is determined, as always, somewhere in between, and can only be so done by the appropriate economic and mathematical models.

The theory and methodology of building transport systems are studied by Gorev (2010), and Beliy, Kokaev, Popov (2002). The interactions of different types of transport are investigated by Mahamadov (1982) and Pravdin, Negrey, Podkopayeva (1989). The issue of inland waterway transport is covered by Blank, Mytayshvyly, Lehostaev (1983). Smehov (1998), and Ortuzar, Willumsen (2008) have built the mathematical models of transport systems that enable the formalized description of their activities. The improvement of port tariffs and interactions with ports customers are researched by Shulpyn, Mynenko (2001) and Makushev (2001). Kholodenko (2001) has performed the optimization of port tariffs for different costs of port services and port tariffs competitors.

However, the existing publications do not consider different possible situations when the rate of the increase in port charges has reduced the number of calls as linear or faster or slower (relevant functions are linear, convex up or down).

The purpose of this article is to optimize the rates of port charges on inland waterways in various fundamental types of the number of ship calls from these rates by constructing and analyzing appropriate mathematical models. 


\section{General economic and mathematical model of the rate of the port charge optimization}

In order to build the model let us assume the following notations:

$n$ - number of ship calls;

$P$ - rate of port charges for ship calls;

$z$ - average costs of the port service for ship calls;

$F$ - profit or loss as the difference between the port charges and the costs of port service for ship calls, i.e. the financial result produced by multiplying the difference between the average $P-z$ port charges and the costs of port service for one vessel ship calls to the number $n$.

$$
F(P)=(P-z(n(P))) \cdot n(P) \rightarrow \max _{P}
$$

To find the best rate of port charges we take the first derivative and equate it to zero:

$$
\begin{gathered}
F_{p}^{\prime}=n_{p}^{\prime} \cdot(P-z(n(P)))+n(P) \cdot\left(1-z_{n}^{\prime} \cdot n_{p}^{\prime}\right), \text { from here: } \\
P=z(n(P))+n(P) \cdot\left(z_{n}^{\prime}-1 / n_{p}^{\prime}\right)
\end{gathered}
$$

i.e. an optimal rate consists of the cost and specific summand proportional to optimal number of ship calls. The positiveness of this summand corresponds to the economic sense and is provided with the logical conditions $z_{n}^{\prime} \geq 0$ (the cost does not decrease with the increasing amount of work, from a certain amount) and $n_{p}^{\prime}<0$ (the demand decreases with the rate growth).

Thus, the optimal rate is the fixed point of continuous mapping (1), which translates the non-empty compact convex set $\left[0 ; z(n(0))+n(0) \cdot\left(z_{n}^{\prime}(0)-1 / n_{p}^{\prime}(0)\right)\right]$ in itself. Under these conditions, this fixed point exists, according to the Brauer theorem (Nikaido 1968).

The second derivative is negative:

$$
F_{P P}^{\prime \prime}=-n_{p p}^{\prime \prime} \cdot \frac{n(P)}{n_{p}^{\prime}}+n_{p}^{\prime} \cdot\left(2-2 \cdot z_{n}^{\prime} \cdot n_{p}^{\prime}-n(P) \cdot z_{n n}^{\prime \prime} \cdot n_{p}^{\prime}\right)<0
$$


under the additional logical conditions $\quad z_{n n}^{\prime \prime} \geq 0 \quad$ (the cost function is convex down on the number of ship calls) and $n_{p p}^{\prime \prime}<0$ (the demand function is convex up on the rate of port charges), so the found optimum rate is exactly maximizing profits.

The view of the dependencies profit as regards the rate of port charges for different values of the port cost (and for these values of competitors' rates) is shown in Figure 1.

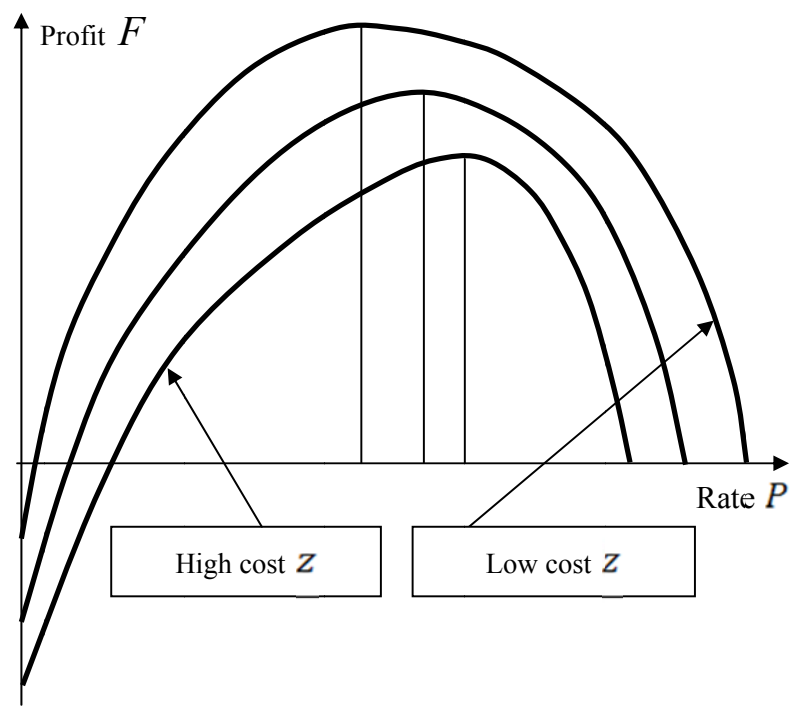

Figure 1. Optimization of port charge rates by the criterion of maximum profit at different costs

Source: own research.

With a low cost, a port can afford to set low rates of interest to customers, with the highest revenue port. With the increasing cost, a port is forced to raise its rates (but on a smaller scale than the cost increases, i.e. the rate of the profit falls) under the reduced customer demand, therefore, the best rates are increasing and the maximum possible profit is decreasing. However, if a port does not increase its rates it will be even worse because of it.

The view of the dependencies profit as regards the port charge rates for different competitor rates (and for these values of ports' cost) is shown in Figure 2. With the high rates of competitors, a port can also set high enough profitable 
rates so as to be relatively attractive also for customers; and with the highest port revenue. With the decreasing competitor rates, a port also has to lower its rates (i.e. the rate of the profit falls), so as not to lose customers, therefore, the best rates and the highest possible as regards the profit fall. However, if a port does not lower its rates, it will be even worse for this port.

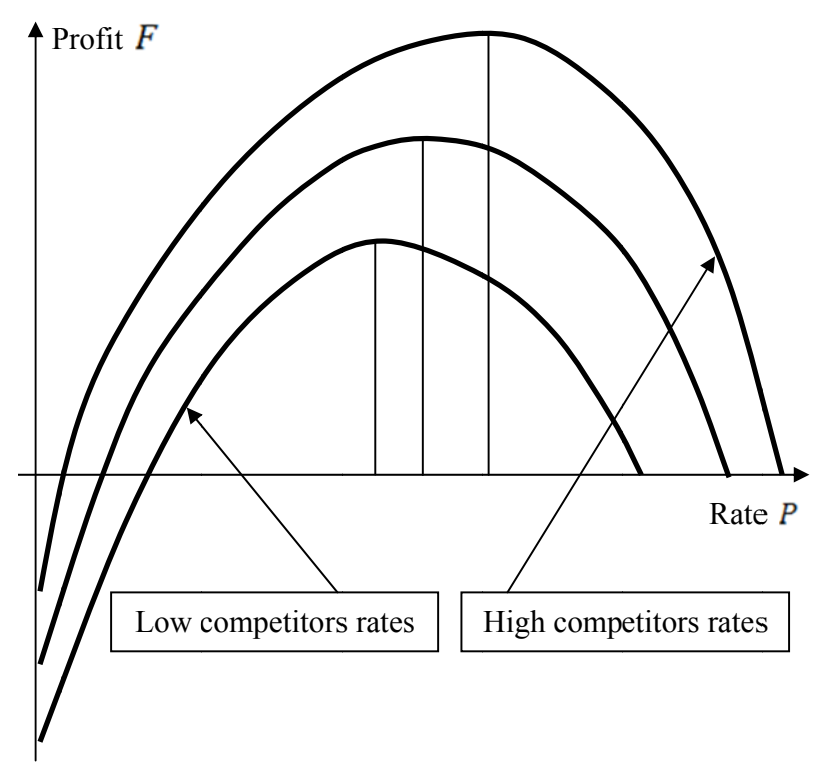

Figure 2. Optimization of port charge rates by the criterion of maximum profit at different competitors rates

Source: own research.

Finally, let us try to demonstrate the impact of both factors - the cost and competitors rates - so as to optimize the port charge rates for one chart (Figure 3). Four bunches of curves correspond to different values of cost (the higher a bunch is situated - the less value of cost it corresponds to, the lower the best value of the rates is).

In turn, the three curves in each bunch correspond to the different values of the competitor rates (in each bunch situated above the rest there is a fat curve corresponding to the higher value of the competitor rates, for which the optimal port rate is higher). Only with the high cost (the lowest bunch) and low own rates (even as regards cost), the high competitors' rates do not lead to higher profits, the port fat curve appears below the others. 


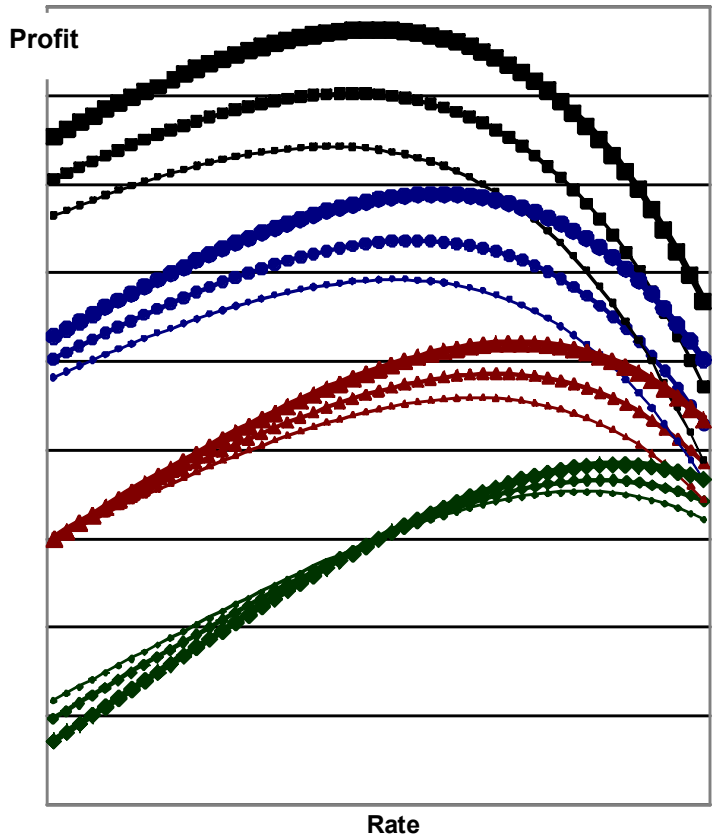

Figure 3. Optimization of port charge rates by the criterion of maximum profit at different costs and competitors rates

Source: own research.

It is clear that with the growing rates of port charges, $P$ number of ship calls $n$ to shrink (otherwise there would be an indefinite increase in this rate - and a corresponding increase in the financial income), but this reduction may occur at different rates - evenly (linearly), rapidly (the number of ship calls as a function of the port charge rates convex upwards) and delayed (the corresponding function is convex down).

Let us set that:

a $>0$ - the maximum possible number of ship calls;

$\mathrm{b}>0$ - reducing the number of ship calls by the unit growth of port charges;

and consistently consider these three possible situations. 


\section{Linear reduction of ship calls $n$ with increasing rates of port charges $P$}

In the simplest case of the linear reduction of ship calls, the number of the ship calls $n$ dependence of the rate of the port charges $P$ will appear as follows (Figure 4)

$$
n=a-b \cdot P
$$

The positive value of the ship calls number $n$ provided with the condition $P<a / b$.

We pose the problem of maximizing the financial results of port charges:

$$
F=(P-z) n=(P-z)(a-b \cdot P) \rightarrow \max _{P}
$$

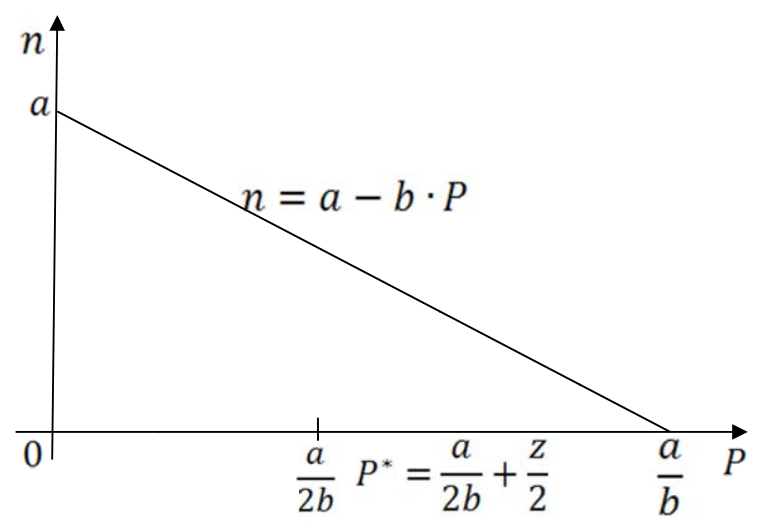

Figure 4. Linear dependence of the ship calls number $n$ from the rates of the port charges $P$

Source: own research.

For its analytical solution, we equate to zero the first derivative:

$$
F_{p}^{\prime}=a-2 b P+b z=0
$$


here we find the optimal value rates of the port charges:

$$
P^{*}=\frac{a}{2 b}+\frac{z}{2}=z+\frac{a-b z}{2 b}
$$

which covers the cost of the port services $z$ and provides a certain financial income $(a-b z>0$ because $z<a / b)$ on each of the ship calls (and the highest possible financial revenues from all ship calls, considering their number).

It is easy to see that $P^{*}=\in\left(\frac{a}{2 b} ; \frac{a}{b}\right)$, i.e. the optimal bid port charge is in the right half of the entire interval of the allowed values $\left[0 ; \frac{a}{b}\right]$ (Figure 4), shifting to the right from the middle of this interval $a / 2 b$ to a half of the port cost $z / 2$.

Substituting (4) into (2), we obtain the optimal number of ship calls:

$$
n^{*}=\frac{a-b z}{2}
$$

Substituting (4) and (5) into (3), we determine the optimal financial result of the port charges:

$$
F^{*}=\frac{(a-b z)^{2}}{4 b}
$$

\section{Accelerated reduction of the ship calls $n$ with the increasing rates of the port charges $P$}

In order to analyze the problem of the accelerated reduction of ship calls considering the increasing rates of the port charges, the simplest function describing this case is quadratic (Figure 5):

$$
n=a-b \cdot P^{2}
$$




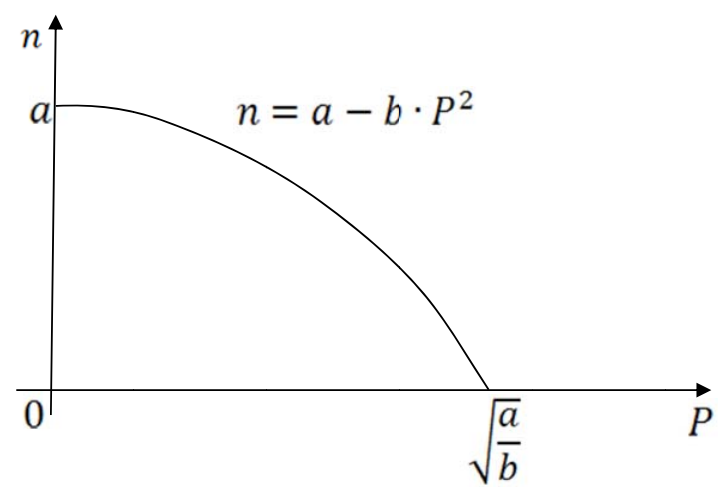

Figure 5. Convex up dependence of the ship calls number $n$ from the rates of the port charges $P$

Source: own research.

The positive value of the ship calls number $n$ provided with the condition: $P<\sqrt{\frac{a}{b}}$. The problem of maximizing financial results of the port charges takes the following form:

$$
F=(P-z) n=(P-z)\left(a-b \cdot P^{2}\right) \rightarrow \max _{P}
$$

For its analytical solution, we equate to zero the first derivative:

$$
F_{p}^{\prime}=a-3 b P^{2}+2 b z P=0,
$$

here we find the optimal value rates of the port charges:

$$
P^{*}=z+\frac{\sqrt{z^{2}+3 \frac{a}{b}}-2 z}{3}
$$


which covers the cost of the port services $z$ and provides a certain financial income $\left(\sqrt{z^{2}}+3 \frac{a}{b}-2 z>0\right.$ because $\left.z<\sqrt{\frac{a}{b}}\right)$ of each of the ship calls (and the highest possible financial revenues from all ship calls, considering their number).

Substituting (9) into (7), the optimal number of ship calls is obtained:

$$
n^{*}=\frac{6 a-2 b z\left(z+\sqrt{z^{2}+3 \frac{a}{b}}\right)}{9}
$$

Substituting (9) and (10) into (8), the optimal financial result of the port charges is determined:

$$
F^{*}=\frac{6 a \cdot \sqrt{z^{2}+3 \frac{a}{b}}-18 a z+2 b z^{3}+2 b z^{2} \cdot \sqrt{z^{2}+3 \frac{a}{b}}}{27}
$$

\section{Slow reduction of the ship calls $n$ with the increasing rates of the port charges $P$}

To analyze the problem of the slow reduction of ship calls considering the increasing rates of the port charges, the simplest function describing this case contains the square root (Figure 6):

$$
n=a-b \cdot \sqrt{P}
$$

The positive value of the ship calls number $n$ is provided with the condition:

$$
P<\left(\frac{a}{b}\right)^{2}
$$




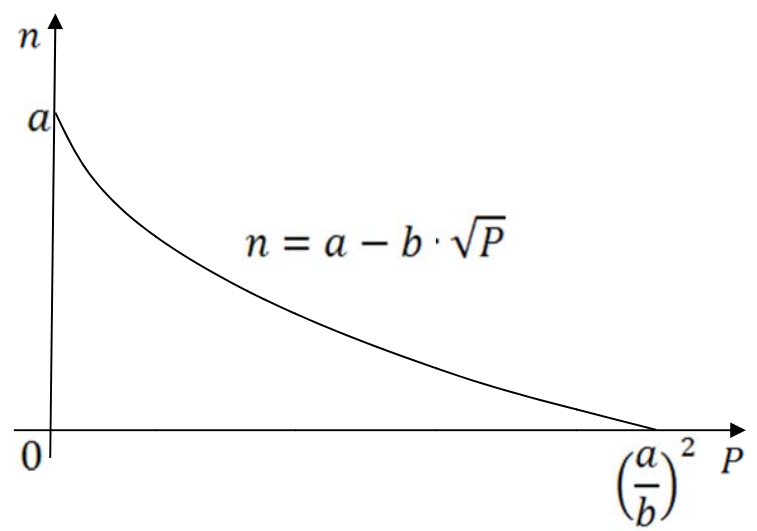

Figure 6. Convex down dependence of the ship calls number $n$ from the rates of the port charges $P$

Source: own research.

The problem of maximizing financial results of the port charges takes the following form:

$$
F=(P-z) n=(P-z)(a-b \cdot \sqrt{P}) \rightarrow \max _{P}
$$

For its analytical solution, we equate to zero the first derivative:

$$
F_{p}^{\prime}=a-\frac{3}{2} b \sqrt{P}+\frac{b z}{2 \sqrt{P}}=0
$$

here we find the optimal value rates of the port charges:

$$
\begin{gathered}
\sqrt{P}=y, 3 b y^{2}-2 a y-b z=0, y=\frac{a+\sqrt{a^{2}+3 b^{2} z}}{3 b}, \\
P^{*}=z+\frac{\left(a+{\sqrt{a^{2}+3 b^{2} z}}^{2}-9 b^{2} z\right.}{9 b^{2}}
\end{gathered}
$$


which covers the cost of the port services $z$ and provides a certain financial income $\left(\left(a+\sqrt{a^{2}+3 b^{2} z}\right)^{2}-9 b^{2} z>0\right.$ because $\left.z<\left(\frac{a}{b}\right)^{2}\right) \quad$ of each of the ship calls (and the highest possible financial revenues from all ship calls, considering their number).

Substituting (14) into (12), the optimal number of ship calls is obtained:

$$
n^{*}=\frac{2 a-\sqrt{a^{2}+3 b^{2} z}}{3}
$$

Substituting (14) and (15) into (13), the optimal financial result of the port charges is determined:

$$
F^{*}=\frac{2 a^{3}+2 a^{2} \sqrt{a^{2}+3 b^{2} z}-18 a b^{2} z+6 b^{2} z \sqrt{a^{2}+3 b^{2} z}}{27 b^{2}}
$$

\section{Summary}

Thus, inland waterways play an important role in the transport system of a country because of their ability to provide large volumes of traffic at low cost. The port charges are an important financial resource for the maintenance of inland waterways and river ports in good condition. The best port charge rate can be determined only by appropriate economic and mathematical models. Such models are built and investigated first in general form, where the necessary condition of the port charge rate optimality is found. This optimal rate is a fixed point of continuous mapping, which translates the non-empty compact convex set in itself. The optimizations of port charge rates by the criterion of maximum profit at different costs and competitors rates are shown on the corresponding visual charts of dependencies.

The models of the port charge rate optimization on internal waterways under three various possible principal kinds (linear, convex up, convex down) of the dependence of ship calls on these rates have also been built. The relevant optimal 
values of the port charge rates and the related amounts of ship calls and financial results have been analytically determined. This enables choosing an adequate for real data type of dependence and determining its parameters by way of mathematical statistics, then substitute these values into the appropriate formulas to obtain the optimal values of port charges to facilitate the development of inland waterways.

\section{References}

Beliy O.V., A.G. Kokaev, S.A. Popov., Architecture and Methodology of Transport Systems, Sankt-Peterburg 2002.

Blank Sh.P., A.A. Mytayshvyly, V.A. Lehostaev., Economics of Inland Waterway Transport, Moscow 1983.

Gorev A.E., Fundamentals of Transport Systems Theory, Sankt-Peterburg 2010.

Kholodenko A.M., Optimization of Port Tariffs, "Development of Management on Transport" 2001, No. 11, Odessa 2001.

Mahamadov A.R., Coordination of Different Species Transport Work, Moscow 1982.

Makushev P.A., Justification of Conditions of Interaction With Ports Customers, "Methods and Tools for Managing the Development of Transport Systems 2001", No. 2, Odessa 2001.

Nikaido H., Convex Structures and Economic Theory, New York and London, Academic Press, 1968.

Ortuzar J.D., L.G. Willumsen., Modeling Transport, 3rd edition, JohnWilley \& Sons Ltd, 2008.

Pravdin N.V., V. Ya. Negrey, V. A. Podkopayeva., Interaction of Different Species Transport, Moscow 1989.

Shulpyn L.V., I.V. Mynenko, On Improvement of Tariff Transport Policy in Ukraine, "Ukraine Transport Complex: Economy, Organization, Development" 2001, No. 9-10, Kiev 2001.

Smehov A.A., Marketing Models of Transport Market, Moscow 1998. 


\section{OPTYMALIZACJA STAWEK OPLAT PORTOWYCH NA DROGACH WODNYCH ŚRÓDLĄDOWYCH}

\section{Streszczenie}

Żegluga śródlądowa odgrywa istotną rolę w systemie transportu kraju ze względu jej zdolność do obsługi wysokich wolumenów ładunków przy niskich kosztach. Opłaty portowe są ważnym źródłem środków finansowych potrzebnych do rozwoju infrastruktury śródlądowych dróg wodnych i portów rzecznych. Najbardziej optymalne stawki opłat portowych mogą być określone tylko poprzez odpowiednie modele matematyczne i ekonomiczne. Takie modele są budowane i badane najpierw w formie ogólnej, kiedy to określany jest warunek konieczny optymalności stawki opłat portowych.

Optymalizację stawek opłat portowych w uwzględnieniem kryterium maksymalnego zysku przy różnych wielkościach kosztów i stawek konkurentów przedstawiono na odpowiednich wykresach. Zbudowane zostały modele optymalizacji stawek opłat portowych w żegludze śródlądowej dla trzech różnych możliwych głównych rodzajów zależności zawinięć statków od tych stawek (liniowa, wypukła, wklęsła). Optymalne wartości stawek opłat portowych powiązanych z ilością zawinięć statków oraz wynikami finansowymi ustalono analitycznie. Daje to możliwość wyboru odpowiedniego typu zależności dla rzeczywistych danych i określenia ich parametrów z wykorzystaniem metod statystycznych, a następnie podstawienia tych wartości do odpowiednich wzorów w celu uzyskania optymalnych wartości opłat portowych. Podejście to może być wykorzystane do wsparcia rozwój żeglugi śródlądowej.

Słowa kluczowe: stawki opłat portowych, żegluga śródlądowa, porty śródlądowe, optymalizacja 